\title{
Emerging Trends in Tall Building Design: Environmental Sustainability through Renewable Energy Technologies
}

\author{
Mohammad Arif Kamal ${ }^{1, *}$, Smriti Saraswat ${ }^{2}$ \\ ${ }^{1}$ Faculty of Architecture and Fine Arts, Integral University, Lucknow, India \\ ${ }^{2}$ Department of Architecture and Planning, I.I.T. Roorkee, India \\ *Corresponding Author: architectarif@gmail.com
}

Copyright (C) 2014 Horizon Research Publishing All rights reserved.

\begin{abstract}
Tall buildings are considered as a great consumer of energy which utilized huge amount of resources and materials; produce massive volumes of waste discharge into the environment and more often called as unsustainable buildings. Building materials such as steel and cement with high intensities of embodied energy are required to create the skeletal framework and lay the foundation for their long lasting structures. The growing global pressure to reduce carbon footprint and concerns for creating sustainable habitats, have also greatly ignited the quest to delve for innovative solutions and emerging trends in tall building designs. This paper discusses environmental sustainability in tall buildings with special reference to the application of renewable energy technologies. Further the paper also validates the application of renewable energy technologies by two detailed case study namely Bahrain World Trade Center, Bahrain and The Pearl River Tower, Guangzhou.
\end{abstract}

Keywords All Buildings, Environmental Sustainability, Renewable Energy Technologies

\section{Introduction}

There was a perception until now that the tall buildings are highly energy consumers with little regard for sustainable architecture and more often considered as unsustainable. These large scale tall buildings were regarded as mega guzzlers which consume a lot of energy, utilizes huge amount of resources and materials and produces massive volume of waste discharge into the environment. With hundreds to thousands of people being serviced through the facility, there is extensive use of energy for heating/cooling purposes, lighting, waste management, mobility through elevators etc. [1]. The energy crisis of the seventies increased the problem of high running costs and might have slowed down high rise buildings proliferation up to early 21 st century. At the same time the crisis brought about intensive research into ways and means to reduce energy demand and more interestingly the move towards renewable sources of energy. But recently there has now been a paradigm shift with a new generation of high rise buildings that have been designed with reference to sustainable architecture especially towards renewable sources of energy. Therefore, the onus has now shifted to the built environment to ensure that new structures reduce energy consumption and increase efficiency through the use of renewable energy sources, innovative and green construction materials and technologies, recycling and waste management systems etc. This paper discusses sustainability in tall buildings with special reference to the application of renewable energy in tall buildings.

\section{Research Methodology}

In this paper qualitative method is used. A qualitative analysis of environmental sustainability in tall buildings with special reference to the application of renewable energy technologies. Further the paper also validates the application of renewable energy technologies by two detailed case study namely Bahrain World Trade Center, Bahrain and The Pearl River Tower, Guangzhou.

\section{Definition of a Tall Building}

Generally, a tall building is regarded as a building which is greater than 20 storeys. However, a tall building is really defined with respect to the height of the surrounding buildings. According to The Council on Tall Buildings and Urban Habitat, a tall building is a building in which "tallness" strongly influences planning, design, construction and use. It is a building whose height creates conditions different from those that exist in common buildings [2].By some standards and estimations, buildings are classified as high-rises when their heights range from 23-150 meters, while anything above 150 meters might be classified as a skyscraper. Any high rise building or skyscraper can be considered as a tall building with a small footprint and small roof area with tall facades. Tall building can be commercial, residential, hotel 
or mixed use with a requirement for building services and not industrial processes or multi storey car parks. The Council on Tall Buildings and Urban Habitat (CTBUH) defines the following categories for a "tall building":

a) Height Relative to Context (not particularly high, but, distinctly taller than the urban norm)

b) Proportion (not particularly high, but, slender enough to appear as a tall building)

c) Tall Building Technologies (having specific vertical transport technologies, structural wind bracing as a product of height, etc.)

\section{Need for Tall Buildings in Present Day Scenario}

The need for tall buildings has arisen for sound economic, social and environmental reasons. Tall buildings are now considered as a viable solution to many of the worlds developed and developing countries and community's problems such as increased population and limited availability of land. They are efficient with respect to land use; serve many people simultaneously from single set of infrastructure and services; respond to demand for popular locations; provide more space and accommodation; and seem imperative for tremendously growing cities of the world and urban densification. A 90 -story building requires less land, less roadway and less urban infrastructure than three 30 -story buildings. A supertall building can incorporate a mixed-use program to offer a live-work or vertical city experience [3]. The large surface areas and high altitude generated in a tall building is apt to harness wind energy (that can be converted and stored as electrical and mechanical energy); solar energy (that can be converted into usable energy for the building in terms of electrical, mechanical and heating); use stack principles for ventilation of the building façade and interior (that saves substantial cost in energy consumptions by artificially regulated means). High-rise buildings provide very high potential with very large surface area that could be utilized to harness solar rays for heating, lighting, buoyancy cooling/ventilation and electricity generation [4].

\section{Environmental Sustainability and Tall Buildings}

Sustainability is achieved through attaining a balance between inter-dependant social, environmental and economic factors. According to Building Services Research and Information Association (BSRIA), definition of sustainable construction is the creation and management of healthy buildings based upon resource efficient and ecological principle [6]. According to the United Nations report in 2001, it is expected that by 2030 the majority of the world population will be concentrated in urban areas. This is particularly evident in developing countries since major cities are susceptible for mass migrations from rural areas in the search for better jobs, services and quality of life. This poses extra pressure on the natural resources and could be detrimental if appropriate measures are not implemented. Bioclimatic tall buildings could provide a sustainable option for accommodating this unprecedented growth of population in urban settings worldwide [7]. Bioclimatic skyscrapers are launched around the world that are sustainable, energy efficient and satisfy the needs of its communities and population. A high performance tall building is one that achieves the peak efficiency of building functions while meeting the requirements of optimum performance employing green technologies. These technologies and innovations offer radical changes to the built environments in terms of energy usage, structural performance, and environmental effects. Designing a sustainable tall building, therefore, requires a 360-degree view of the entire building enterprise considering the local and global environment, the availability of renewable and non-renewable resources, community impact assessment, and the collaborative input of architects, planners, engineers, social scientists, behavioral scientists, and other community-based groups [8].

\section{Sustainability through Renewable Energy Technologies}

For a building to be sustainable, much of the focus should be on the use of energy in building operation. The energy consumed in operation of the building overshadows that of the construction. Typically $90 \%$ is consumed in operation over the lifespan of the building [9]. The most important renewable sources for onsite energy production for sustainable tall buildings are solar, wind, small hydroelectric (for rural uses near a river or stream) and geothermal (the Earth's heat). Using onsite renewable energy, green buildings have a critical role to play in reducing our carbon footprint. These renewable energy technologies help to generate renewable energy using renewable natural resources, thus help in conserving energy. In a report by the American Solar Energy Society, it showed that renewable energy such as solar, wind, biofuels, biomass and geothermal could supply a carbon reduction of more than 500 million metric tons per year, about $40 \%$ of the total needed to meet Kyoto treaty obligations [10]. The renewable energy systems will supply a higher percentage of the building's total energy demand for the same cost than in a less-efficient building. Technological progress has enabled a ten-fold increase in the sizes of wind turbines, from $50 \mathrm{~kW}$ units to $5 \mathrm{MW}$ in 25 years and a cost reduction of more than $50 \%$ over the last 15 years. The average annual growth rate of about $35 \%$ in the past decade makes photovoltaic one of the fastest growing energy industries [11]. The incorporation of renewable energy technologies in tall building have been discussed in with the help of following two prominent case-studies. 


\subsection{Case Study 1: Bahrain World Trade Center, Bahrain}

The Bahrain World Trade Centre (WTC) in Manama, Bahrain is an extension of the existing five-star Sheraton Hotel complex and comprises two 50-storey sail-shaped commercial office towers, which taper to a height of $240 \mathrm{~m}$ and support three $29 \mathrm{~m}$ diameter horizontal-axis wind turbines (Figure 1). The two towers are linked via three sky-bridges, each holding a $225 \mathrm{~kW}$ wind turbine, combining to $675 \mathrm{~kW}$ of wind power production. Each of these turbines is aligned towards north, which is the direction from which air from the Persian Gulf blows in. The sail-shaped buildings on either side are designed to funnel wind through the gap to provide accelerated wind passing through the turbines. This was confirmed by wind tunnel tests, which showed that the buildings create an S-shaped flow, ensuring that any wind coming within a $45^{\circ}$ angle to either side of the central axis will create a wind stream that remains perpendicular to the turbines. This significantly increases their potential to generate electricity [12]. The wind turbines are expected to provide $11 \%$ to $15 \%$ of the towers total power consumption, or approximately 1.1 to $1.3 \mathrm{GWh}$ a year. This is equivalent to providing the lighting for about 300 homes [13]. They are expected to operate $50 \%$ of the time on an average day [14].

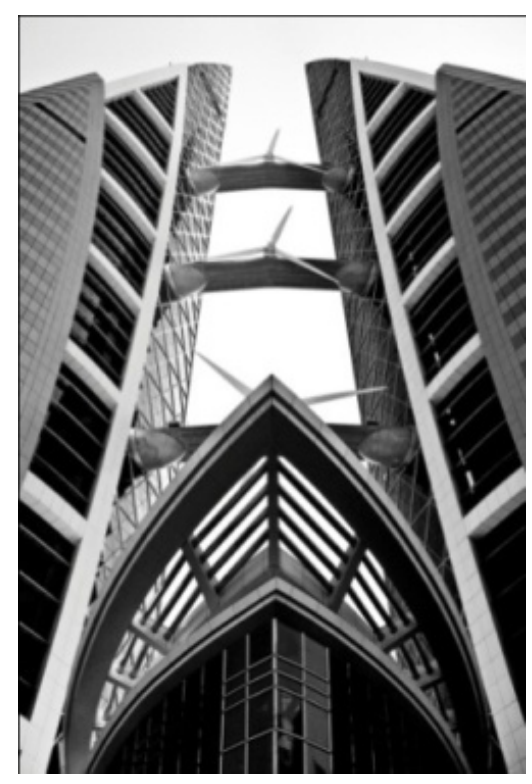

Figure 1. Bahrain World Trade Center showing three giant wind turbines.

The WTC, Bahrain was awarded the Best Tall Building Award, Mena Region for 2008, EDIE Award for Environmental Excellence for 2007 and the LEAF Award for Best Use of Technology within a Large Scheme for 2006. Many design features have been integrated in this building that has helped reduce carbon emissions [15]:

- Buffer spaces between the external environment and air conditioned spaces

- Dynamic Insulation through deep gravel roofs in some locations

- Sloping Elevations have balconies with overhangs to provide shading

- High quality solar glass, where shading is not provided to glazing

- Variable volume chilled water pumping, which operates with considerably less power.

Total heat recovery - energy efficient fluorescent lighting - dual drainage systems - dual flush WC - local evaporative cooling - extensive landscaping

\subsection{Case Study 2: The Pearl River Tower, Guangzhou, China}

Pearl River Tower, located in Guangzhou, China which is under construction is a green skyscraper designed by Skidmore, Owings \& Merrill. The building is 309 meters tall having 71 stories. It is a high performance building that claims to be the most energy efficient super - tall tower building in the world (Figure 2). The design approach included four important interdependent steps [16]:

a) Reduction (reduce the amount of energy consumed)

b) Absorption (utilize the natural and passive energy sources that pass around, over and under the building's envelope)

c) Reclamation (harvest the energy already resident within the building - this energy can be reused over and over again)

d) Generation ("micro - turbine" gas turbine generation technology to enable generation of power more efficiently than the city's grid, which was eventually eliminated because of several reasons).

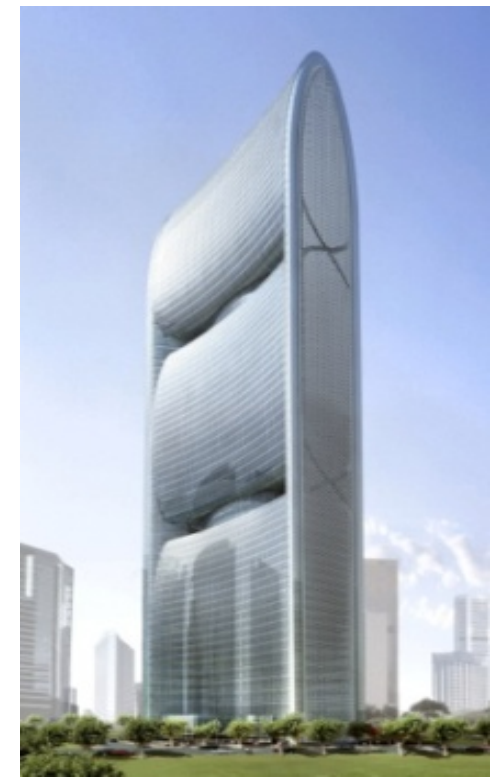

Figure 2. Pearl River Tower, Guangzhou

The building has double wall insulation. The double envelope accommodates venting and solar shading devices within the cavity (Figure 3). These design approaches facilitate thermal comfort and air quality, as well as 
day-lighting and energy savings.

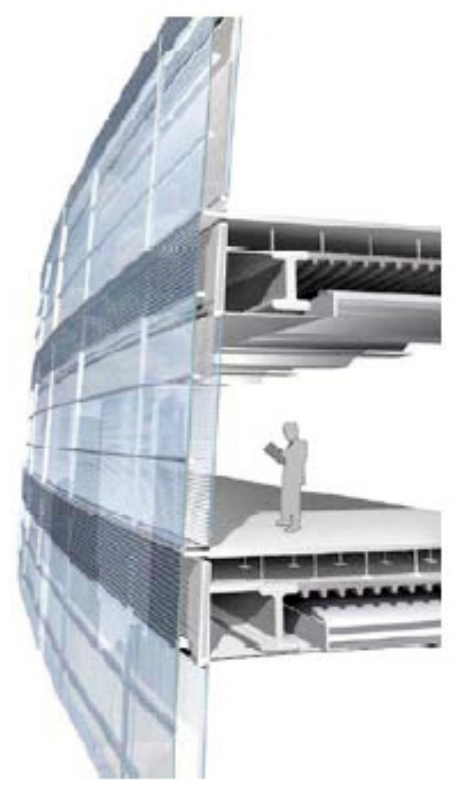

Figure 3. High Performance Active Facade Detail

The building has embedded photovoltaic transistor system for solar energy. The Building Integrated Photovoltaics (BIPVs) in the Pearl River Tower act both as the building skin (spandrel panels) as well as power generator (Figure 4). The wall surfaces are angled for maximum sun exposure. The building is designed in such a way that it funnels and pushes the air through wind tunnels at a great speed which is 1.5 to 2.5 times greater than the ambient wind speed. It has a curved glass facade that directs air flow through narrow openings in the facade that will drive large, stainless steel wind turbines to generate electrical energy. It generates 15 times more energy than the 'freestanding' wind turbines. Wind has a great impact on the design of tall buildings. When the air is allowed to pass through the building, the difference in pressure between the windward side and the leeward side is reduced. As a result, the forces on the building are also reduced (Figure 6). This approach allows for a reduction in the quantity of steel and concrete to maintain the building's stability. Hence, it is a sustainable approach towards design as far as structural standpoint is considered. Moreover, vertical axis wind turbines are implemented in the building, which are capable of harnessing winds from both prevailing directions and greatly reduce efficiency loss (Figure 5). The building utilizes the emergency energy from natural gas fuel cells. It also uses gas to electrochemically break down hydrogen, which is $50 \%$ more efficient than obtaining electricity through outside sources. The waste gases are recycled to power the HVAC system. This building also employs geothermal heat sinks, ventilated facades, waterless urinals, integrated photovoltaic and daylight responsive controls. According to reports, Pearl River Tower would help emit less carbon dioxide by approximately 3,000 tons and achieve an overall energy saving of $30.4 \%$ a year [17].

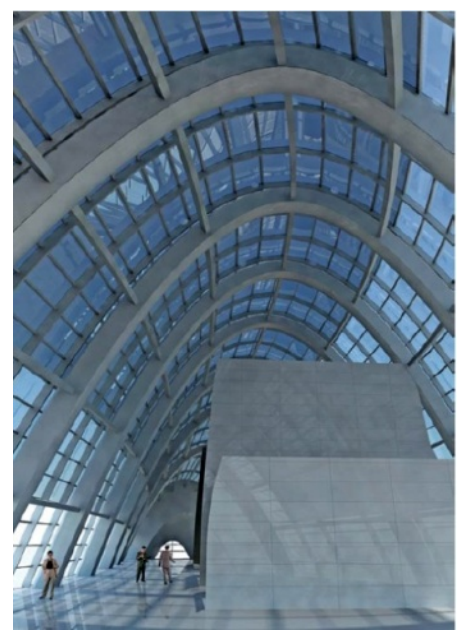

Figure 4. Building Integrated Photovoltaic

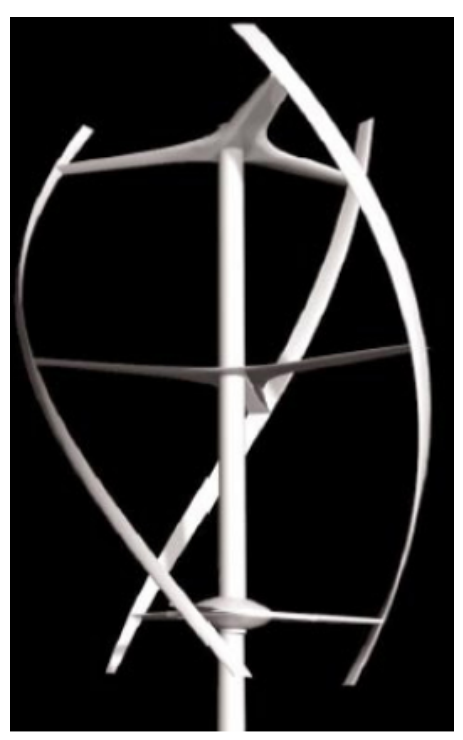

Figure 5. Vertical Axis Wind Turbine

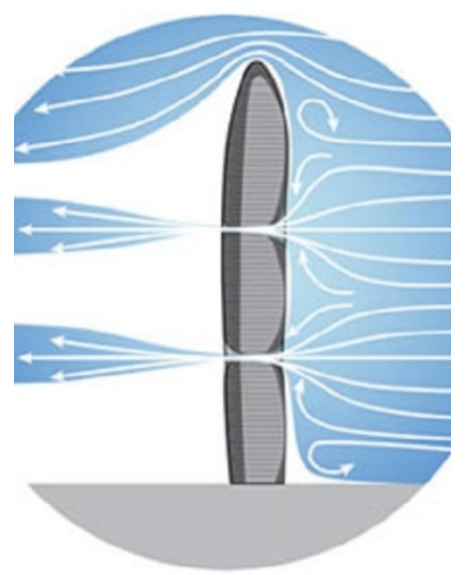

Figure 6. Pearl River Tower showing the functioning of wind turbines

Varied sustainable design strategies included in the design of Pearl River Tower have resulted in a significant reduction in the amount of energy needed to operate in the building (Figure 7). 


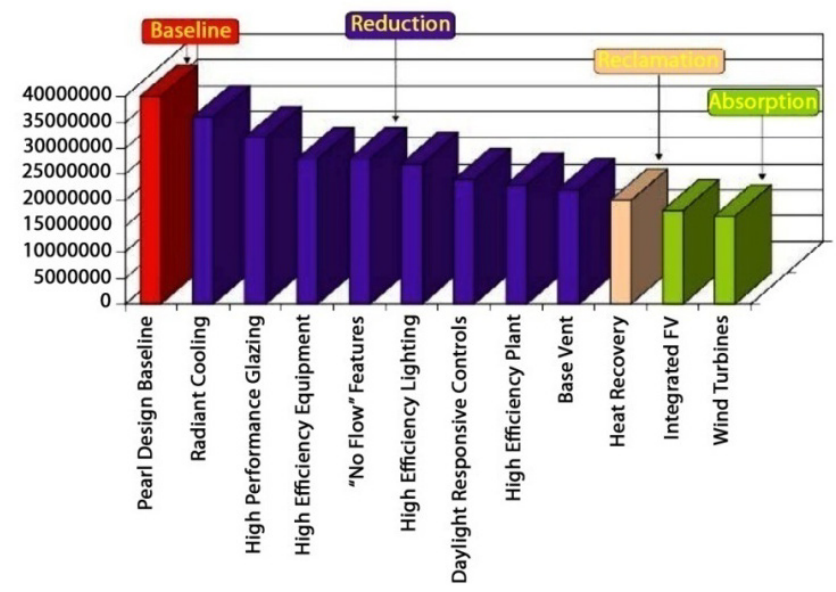

Figure 7. Overall energy reduction for sustainable strategies in Pearl River Tower

\section{Conclusion}

The search for available renewable energy sources, technologies to harness them (such as heat provision from passive and active solar systems, ambient air, geothermal energy, electricity generation from solar radiation, wind energy, hydropower, ocean energy, biomass energy), and their economic and environmental assessment, have become absolutely important. The use of solar power systems and wind energy has the potential to help meet growing energy demand and can provide diversity and reliability in energy supplies. Around $35 \%$ of the renewable energy contribution is from the wind energy while the rest is divided evenly amongst the other technologies. Wind energy is a clean renewable source of energy as it is fueled by the natural wind and it is also one of the lowest-priced renewable energy technologies available today. Wind power with suitable collecting/converting devices has very high potential due to the acceleration of wind profile with height in urban areas. Tall buildings by virtue of their height can benefit from high level of wind speeds in the mainstream of the atmospheric boundary layer. Tall buildings could be considered as increasingly viable building types in the future, considering the rapidly increasing needs for higher urban densities. But, they have to be judiciously designed by integrating renewable energy technologies, also keeping in mind the vernacular ethos of the place. Incorporation of these renewable energy technologies in tall building will certainly reduce our dependency on fossil fuel and minimize the environmental problems due to excessive consumption of energy and other natural resources. Hence the integration of renewable energy technologies in tall buildings has proved to be a great initiative, which can accelerate our march towards sustainability.

\section{REFERENCES}

[1] Building from the ground-up towards sustainability, Online available from http://www.rics.org/site/scripts/documents in fo.aspx?documentID=859\&pageNumber $=10$

[2] Council on Tall Buildings and Urban Habitat - CTBUH, Architecture of Tall Buildings, McGraw-Hill, Inc. New York, 1995.

[3] G. Gordon, Best Tall Buildings 2010: CTBUH International Award Winning Projects, Routledge, USA and Canada, 2011.

[4] A. Elbakheit, Effect of Duct Width in Ducted Photovoltaic Facades, Proceedings CTBUH 8th World Congress, Dubai. March 3 - 5, 2008, pp.795 - 801, 2008.

[5] Brundtland Commission Report, Our Common Future, Report of the World Commission on Environment \& Development, Oxford University Press, London, 1987.

[6] B. Edwards, P. Hyett. Rough Guide to sustainability. RIBA Publications, London, 2001.

[7] United Nations. Future World Population Growth to be Concentrated in Urban Areas, United Nations Population Division Report, 2001.

[8] B Donaldson, P. Lippe. Process and Integration, Lessons Learned: High Performance Buildings, The Durst Organization. New York, 2000.

[9] B. N. Winther, A. G. Hestnes. Solar versus green: the analysis of a Norwegian row house, Solar Energy,Vol. 66, No. 6, pp 387-393, 1999.

[10] Climate Change, Online available from http://ases.org/ climatechange/climate_change.pdf

[11] Liberali R, Renewable Energy Technologies: Long Term Research in the 6th Framework Programme 2002 - 2006, Online available from http://ftp.cordis.europa.eu/pub/fp7/ene rgy/docs/synopses_res_en.pdf

[12] Bahrain World Trade Centre, Online available from http:/www.designbuild-network.com/Projects/bahrain-world -trade-centre.

[13] Bahrain Wind Power, Online available from http://www.reut ers.com/article/2007/03/19/us-bahrain-windpower-idUSL19 28644820070319

[14] World Architecture News, BWTC turbines spin for first time, World Architecture News, 2008.

[15] Killa, Shaun, Smith and F. Richard. Harnessing Energy in Tall Buildings: Bahrain World Trade Center and Beyond, Conference Proceeding, CTBUH 8th World Congress, Dubai, 2008.

[16] R. Frechette, R. Gilchrist. Towards Zero Energy: A Case Study of the Pearl River Tower, Guangzhou, China, Conference Proceeding, Council on Tall Buildings and Urban Habitat - CTBUH, 8th World Congress, Dubai, 2008.

[17] Pearl River Tower, Online available from http://solarairtech.com/news/24-chinas-pearl-river-tower-aim s-for-zero-net-impact-on-energy-consumption.html. 